\title{
The Cytotoxicity of Benzaldehyde Nitrogen Mustard-2-Pyridine Carboxylic Acid Hydrazone Being Involved in Topoisomerase II $\alpha$ Inhibition
}

\author{
Yun Fu, ${ }^{1}$ Sufeng Zhou, ${ }^{2}$ Youxun Liu, ${ }^{1}$ Yingli Yang, ${ }^{1}$ Xingzhi Sun, ${ }^{1}$ and Changzheng Li ${ }^{1}$ \\ ${ }^{1}$ Department of Molecular Biology \& Biochemistry, Xinxiang Medical University, 601 Jinsui Road, Xinxiang, Henan 453003, China \\ ${ }^{2}$ Clinical Skill Training Center, Xinxiang Medical University, Xinxiang, Henan 453003, China \\ Correspondence should be addressed to Changzheng Li; changzhenl@yahoo.com
}

Received 17 February 2014; Accepted 12 May 2014; Published 5 June 2014

Academic Editor: Bruno C. Cavalcanti

Copyright (C) 2014 Yun Fu et al. This is an open access article distributed under the Creative Commons Attribution License, which permits unrestricted use, distribution, and reproduction in any medium, provided the original work is properly cited.

\begin{abstract}
The antitumor property of iron chelators and aromatic nitrogen mustard derivatives has been well documented. Combination of the two pharmacophores in one molecule in drug designation is worth to be explored. We reported previously the syntheses and preliminary cytotoxicity evaluation of benzaldehyde nitrogen mustard pyridine carboxyl acid hydrazones (BNMPH) as extended study, more tumor cell lines ( $\mathrm{IC}_{50}$ for HepG2: $26.1 \pm 3.5 \mu \mathrm{M}$, HCT-116: 57.5 $\pm 5.3 \mu \mathrm{M}, \mathrm{K} 562: 48.2 \pm 4.0 \mu \mathrm{M}$, and PC-12: $19.4 \pm 2.2 \mu \mathrm{M}$ ) were used to investigate its cytotoxicity and potential mechanism. In vitro experimental data showed that the BNMPH chelating $\mathrm{Fe}^{2+}$ caused a large number of ROS formations which led to DNA cleavage, and this was further supported by comet assay, implying that ROS might be involved in the cytotoxicity of BNMPH. The ROS induced changes of apoptosis related genes, but the TFR1 and NDRG1 metastatic genes were not obviously regulated, prompting that BNMPH might not be able to deprive Fe ${ }^{2+}$ of ribonucleotide reductase. The BNMPH induced S phase arrest was different from that of iron chelators (G1) and alkylating agents (G2). BNMPH also exhibited its inhibition of human topoisomerase II $\alpha$. Those revealed that the cytotoxic mechanism of the BNMPH could stem from both the topoisomerase II inhibition, ROS generation and DNA alkylation.
\end{abstract}

\section{Introduction}

Cancer is an important health issue that caused million deaths. Localized cancer can be resected by surgery, but metastasis cancer has to be treated systematically by chemotherapy in combination with radiotherapy [1]. However, chemotherapeutic agents used are cytotoxic in genetics and have some side effects due to lack of selectivity toward tumor cells. One approach to improving the therapeutic effectiveness and decreasing systemic side effects is through the design of anticancer drug based on the tumor cell characteristic. It is well known that iron is an essential element and that it plays a crucial role in cellular proliferation and DNA synthesis. In general neoplastic cells have high requirement for iron for their significantly elevated expression of the transferrin receptor 1 (TfR1) [2]. Similarly, the higher levels of the Fe-containing enzyme, ribonucleotide reductase (RR), for DNA synthesis are also found in neoplastic cells. In addition, it has been shown that cancer cells also take up more copper $(\mathrm{Cu})$ than normal cells and use this metal for angiogenesis and metastasis [3]. Based on the crucial roles of these metals, developing novel $\mathrm{Fe}$ and $\mathrm{Cu}$ chelators has become a promising anticancer strategy [4]. Desferrioxamine (DFO) and Dp44mT are examples of this kind of metal chelators and have excellent antitumor activity $[5,6]$.

Nitrogen mustard as alkylating agent is one of the most useful drugs in cancer chemotherapy. Due to the lack of selectivity and toxic side effect as well as resulting drug resistance, carcinogenesis and mutation, its applications are limited. To improve its antitumor activity, many strategies are tried to design specific target alkylating agents, such as DNA-directed alkylating agents which were made by linking DNA-affinic molecules (carriers) to a nitrogen mustard pharmacophore (warhead) for these DNA-affinic molecules also exhibit topoisomerases I and II inhibition [7, 8]. In those strategies the aromatic nitrogen mustards are mostly used 


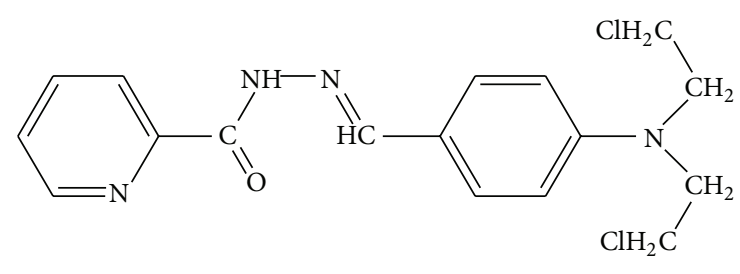

FIGURE 1: The chemical structure of BNMPH.

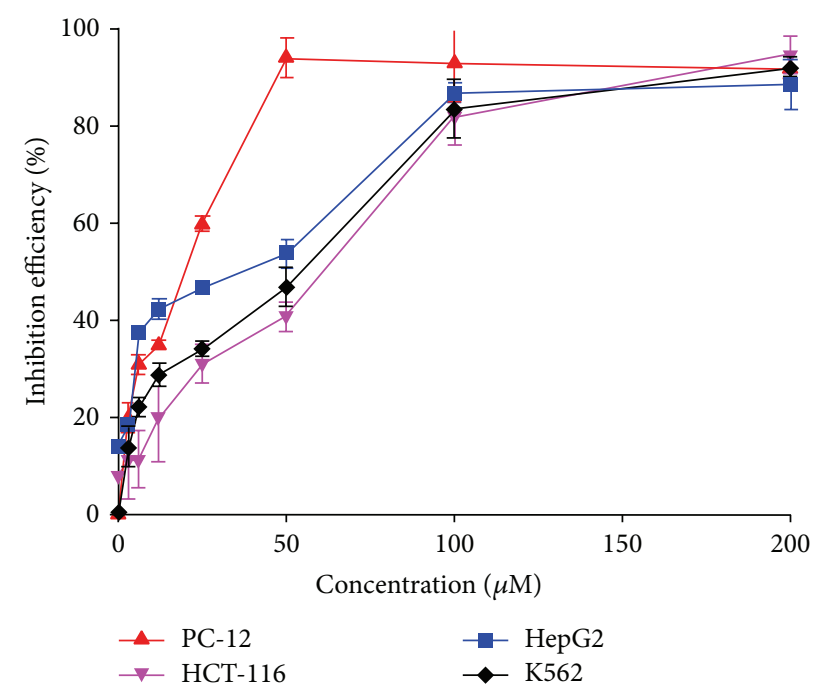

FIgUre 2: Cytotoxicities of BNMPH in the indicated cell lines $\left(\mathrm{IC}_{50}\right.$ : $57.5 \pm 5.0 \mu \mathrm{M}$ for HCT-116; $19.4 \pm 2.2 \mu \mathrm{M}$ for PC-12; $26.1 \pm 3.5 \mu \mathrm{M}$ for HepG2; and $48.2 \pm 4.0 \mu \mathrm{M}$ for K562).

as alkylating pharmacophore (such as benzoic acid nitrogen mustard) as they are effective against quiescent cell and trend to be less susceptible to induced resistance than most anticancer drugs.

Combining two pharmacophores into one molecule could make it with dural targets, which may both enhance its cytotoxicity and reduce resistance when administrated. As mentioned above, iron chelator can interfere with iron metabolism by depriving iron either from enzymes (proteins) or from labile iron pool. And tumor cells require more iron for their growth. The drug tethering both alkylating and chelating groups is another option to attempt improving its biological activity. We made some hydrazones by condensation of pyridine carboxyl acid hydrazides with benzaldehyde nitrogen mustard $[9,10]$, indicating that the hydrazones indeed enhance their antitumor activities compared to the parent compounds. As extended study, more cancer cell lines were used to explore the potential mechanism; the results indicated that the hydrazone exerts its cytotoxicity via disturbing host cell cycle, inhibiting topoisomerase II and regulating apoptosis related genes. However, the introduction of chelating group which desires to regulate metastasis genes seems not to disturb the iron metabolism.

\section{Materials and Methods}

All reactants and solvents were AR grade. MTT, ethidium bromide (EB), RPMI-1640, and agarose were purchased from Sigma.

2.1. Preparation of Benzaldehyde Nitrogen Mustard-2-Pyridine Carboxyl Acid Hydrazone (BNMPH). Benzaldehyde nitrogen mustard-2-pyridine carboxyl acid hydrazone was made as described [9]. The BNMPH structure is shown in Figure 1.

2.2. The Cytotoxicity of the BNMPH. The stock solution of $\mathrm{BNMPH}$ was prepared in DMSO; $1 \mathrm{mg} / \mathrm{mL}$ cisplatin (in physiological saline) was used as positive control. The BNMPH solution was diluted to the required concentration with culture when used. The Human colorectal carcinoma cell line (HCT-116), human erythromyeloblastoid leukemia cell line (K562), and liver carcinoma cells (HepG2) were cultured in RPMI 1640 medium supplemented with 10\% fetal calf serum (mycoplasma free FCS) and antibiotics. The rat pheochromocytoma cell line (PC-12) was cultured as HepG2 except $10 \%$ horse serum supplemented. The cells collected from exponential phase $\left(2 \times 10^{4} / \mathrm{mL}\right)$ were seeded equivalently into 96-well plate and the various amounts of BNMPH were added after the cells adhered. Following $48 \mathrm{~h}$ incubation at $37^{\circ} \mathrm{C}$ in a humidified atmosphere of $5 \% \mathrm{CO}_{2}$, $10 \mu \mathrm{L}$ MTT solution $(1 \mathrm{mg} / \mathrm{mL})$ was added to each well, followed by further incubation of $4 \mathrm{~h}$. The cell culture was removed by aspiration, and $100 \mu \mathrm{L}$ DMSO was added in each well to dissolve the formazan crystals. The measurement of absorbance of the solution that was related to the number of live cells was performed on a microplate reader (MK3, Thermo Scientific) at $492 \mathrm{~nm}$. Percent growth inhibition was defined as percent absorbance inhibition within appropriate absorbance in each cell line. The same assay was performed in triplet.

2.3. ROS Detection and DNA Cleavage Caused by BNMPH. $\mathrm{H}_{2}$ DCF-AM was converted to dichlorofluorescein (DCF) according to reports by Jakubowski and Bartosz [11]. Briefly, $0.25 \mathrm{~mL}$ of $2 \mathrm{mM} \mathrm{H}_{2}$ DCF-AM in absolute ethanol was added to $2.0 \mathrm{~mL}$ of $10 \mathrm{mM} \mathrm{NaOH}$ and allowed to stand at room temperature for $30 \mathrm{~min}$. The hydrolysate was then neutralized with $10 \mathrm{~mL}$ of $25 \mathrm{mM}$ sodium phosphate buffer ( $\mathrm{pH} 7.2$ ) and kept on ice for use. Reaction buffer $(50 \mathrm{mM}$ sodium phosphate buffer, $\mathrm{pH}$ 7.4) containing $0.4 \mu \mathrm{M}$ DCF was mixed with $25 \mu \mathrm{L}$ of $1 \mathrm{mM}\left(\mathrm{NH}_{4}\right)_{2} \mathrm{Fe}\left(\mathrm{SO}_{4}\right)_{2}$ or $1 \mathrm{mM} \mathrm{BNMPH}$ or $0.2 \mathrm{~mL}$ of $4 \mathrm{mM} \mathrm{H}_{2} \mathrm{O}_{2}$ in a total volume of $4.0 \mathrm{~mL}$. The fluorescence of each sample was measured in FC-960 spectrofluorimeter (excitation at 488 and emission at $520 \mathrm{~nm}$ ). The measurements were conducted at room temperature.

The ROS induced DNA cleavage was assessed as described [12], and the concentration was used in the assay as indicated in Figure 3(b).

2.4. Comet Assay. The single-cell gel electrophoresis (comet assay) was adapted from the method as described [13]. HepG2 cells treated with or without $50 \mu \mathrm{M}$ of BNMPH after $48 \mathrm{~h}$ 


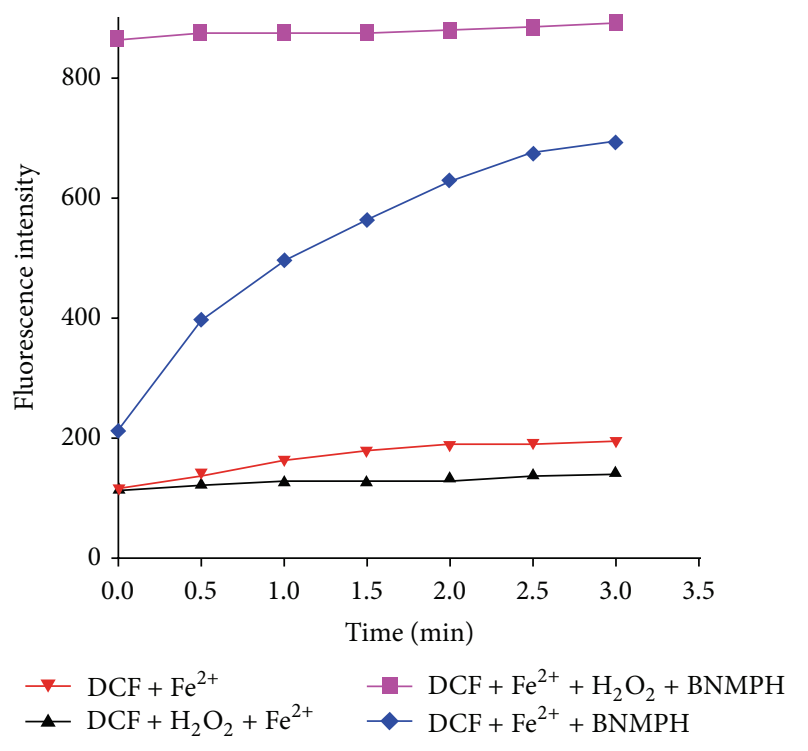

(a)

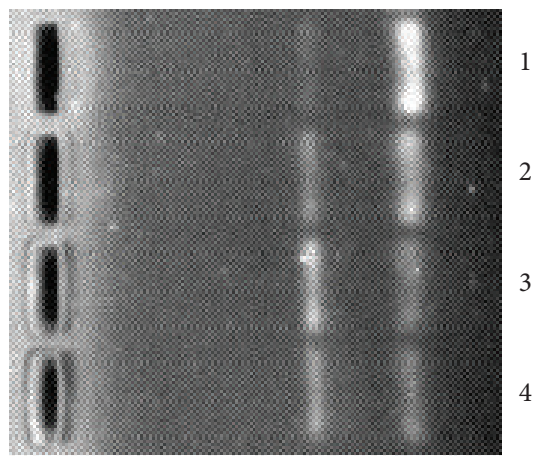

$\begin{array}{ll}\text { (1) No BNMPH } & \text { (3) } 100 \mu \mathrm{M} \text { BNMPH }\end{array}$

$\begin{array}{ll}\text { (2) } 50 \mu \mathrm{M} \text { BNMPH } & \text { (4) } 150 \mu \mathrm{M} \text { BNMPH }\end{array}$

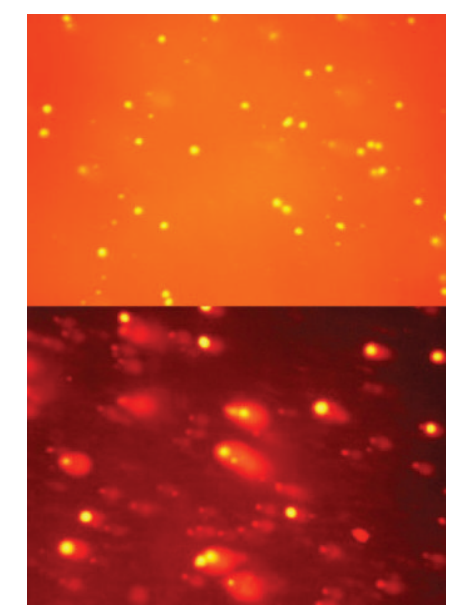

(b)

(c)

FIGURE 3: BNMPH redox activity and induction of DNA fragmentation. (a) ROS generation by Fenton reaction; the ROS product was measured by DCF fluorescence. (b) The ROS induced DNA fragmentation in the presence or absence of BNMPH; the fragmented DNA was separated by agarose gel electrophoresis and visualized by EB staining, and the concentration is as indicated. (c) DNA fragmentation in vivo was evaluated by comet assay, top: control, and bottom: in the presence of $50 \mu \mathrm{M}$ BNMPH.

incubation in a humidified atmosphere of $5 \% \mathrm{CO}_{2}$ were harvested by centrifugation at $1000 \mathrm{rpm}$ and then embedded in $0.5 \%$ low-melting-point agarose at a final concentration of $10^{4}$ cells $/ \mathrm{mL} .20 \mu \mathrm{L}$ of this cellular suspension was then spread onto duplicate frosted slides that had previously been covered with $1 \%$ normal melting point agarose as a basal layer. Slides were allowed to solidify for $10 \mathrm{~min}$ at $4^{\circ} \mathrm{C}$ before being placed in lysis buffer for $1 \mathrm{~h}(2.5 \mathrm{M} \mathrm{NaCl}, 0.1 \mathrm{M}$ ethylene diamine tetraacetic acid (EDTA), $0.01 \mathrm{M}$ Tris, $1 \%$ Triton X-100, and $10 \%$ dimethyl sulfoxide (DMSO), $\mathrm{pH} 10$ ). After lysis, the slides were transferred into alkaline buffer for $40 \mathrm{~min}(0.001 \mathrm{M}$ EDTA, $0.3 \mathrm{M} \mathrm{NaOH}, \mathrm{pH}>13$ ) to allow the DNA to unwind before migration at $0.66 \mathrm{~V} / \mathrm{cm}$ and $300 \mathrm{~mA}$ for $30 \mathrm{~min}$. All these steps were performed in the dark. After neutralisation in $0.4 \mathrm{M}$ Tris $\mathrm{HCl} \mathrm{pH} \mathrm{7.4,} \mathrm{slides} \mathrm{were} \mathrm{stored} \mathrm{at} 4^{\circ} \mathrm{C}$ until analysis within the following $24 \mathrm{~h}$. Before analysis, the slides were stained with ethidium bromide (EB) $(20 \mu \mathrm{g} / \mathrm{mL})$ and covered with a cover slip. The photograph was taken on fluorescent microscopy.

2.5. Alkaline Agarose Gel Shift Assay. DNA cross-linking of BNMPH was assayed by alkaline agarose gel electrophoresis as described [8]. In brief, purified pUC18 plasmid DNA $(1 \mu \mathrm{g})$ was mixed with various concentrations $(12.5-50 \mu \mathrm{M})$ of BNMPH in $10 \mu \mathrm{L}$ reaction buffer $(10 \mathrm{mM}$ sodium phosphate, $\mathrm{pH} 7.4$ containing $3 \mathrm{mM} \mathrm{NaCl}$ and $1 \mathrm{mM}$ EDTA). The reaction mixture was kept at $37^{\circ} \mathrm{C}$ for $2 \mathrm{~h}$. Finally, the plasmid DNA 
was digested to linear DNA with Xba I and followed by phenol extraction and ethanol precipitation. The DNA pellets were dissolved in alkaline buffer ( $0.5 \mathrm{M} \mathrm{NaOH}, 10 \mathrm{mM}$ EDTA), mixed with alkaline loading dye, and then electrophoresed on a $1 \%$ alkaline agarose gel with $\mathrm{NaOH}$-EDTA buffer at $4^{\circ} \mathrm{C}$. The electrophoresis was carried out at $30 \mathrm{~V}$ for $2 \mathrm{~h}$. After staining the gels with an ethidium bromide solution, the DNA was then visualized on Toucan 360 gel imager (version 3.2.1 software).

2.6. Thermal Denaturation. The DNA melting experiments were carried out in the temperature range from 25 to $95^{\circ} \mathrm{C}$ with a Shimadzu circulation bath, monitoring the absorbance of Ct-DNA at $260 \mathrm{~nm}$ in the absence or presence of BNMPH. The melting temperature (Tm) of DNA is defined as the temperature at which $50 \%$ of double strand becomes single stranded. It was determined as the midpoint of the optically detected transition curves [14].

2.7. Cell Cycle Analysis. HepG2 cells $\left(1 \times 10^{5}\right)$ were seeded in a six-well plate. After $24 \mathrm{~h}$ of incubation at $37^{\circ} \mathrm{C}\left(5 \% \mathrm{CO}_{2}\right)$, the medium was changed with fresh, supplemented or not (control) with BNMPH $(6,12 \mu \mathrm{M})$. After $24 \mathrm{~h}$ of incubation, cells were harvested with trypsin, washed by PBS, fixed in $70 \%$ ethanol, and stored at $-20^{\circ} \mathrm{C}$. The cellular nuclear DNA was stained by propidium iodide (PI). Briefly, after removing the $70 \%$ ethanol, the cells were washed with PBS and then suspended in $0.5 \mathrm{~mL}$ PBS containing $50 \mu \mathrm{g} / \mathrm{mL}$ PI and $100 \mu \mathrm{g} / \mathrm{mL}$ RNase. The cell suspension was incubated at $37^{\circ} \mathrm{C}$ for $30 \mathrm{~min}$. DNA flow cytometry was performed in duplicate with a FACScalibur flow cytometer (Becton Dickinson, USA). Each sample's 10000 events were collected and fluorescent signal intensity was recorded and analyzed by CellQuest and Modifit (Becton Dickinson, USA).

2.8. The Effect of the BNMPH on Apoptotic and Metastatic Gene Regulation by RT-PCR. To explore the underlying mechanism, the HepG2 cells were treated with the BNMPH. The RT-PCR was conducted to determine both the changes of apoptotic genes such as p53, caspase-3, and caspase- 8 and metastatic genes, such as TFR1 and NDRG1 at mRNA level. The gene expressions investigated were measured after $24 \mathrm{~h}$ incubation with different concentrations of BNMPH. Total RNA was extracted from the cells using Trizol reagent (Sangon, Shanghai, China) according to the manufacturer's protocol. Three micrograms of total RNA was used for reverse transcription in a total volume of $20 \mu \mathrm{L}$ with the M-MLV reverse transcriptase system (LifeFeng Biotechnology Co., Shanghai, China). $2 \mu \mathrm{L}$ cDNA was subsequently amplified in a total volume of $20 \mu \mathrm{L}$ using the $2 x$ Taq PCR kit (LifeFeng Biotechnology Co., Shanghai, China) following conditions recommended by the manufacturer. The sense and antisense primers (primers were synthesized by Shanghai General Bioengineering Co. in the study, Shanghai, China) for beta actin were $5^{\prime}$-ACACTGTGCCCATCTACGAGG-3' and $5^{\prime}$ CGGACTCGTCATAC TCCTGCT-3' (615 bp). They were used as an internal control; the sense and antisense primers for caspase-3 were $5^{\prime}$-GAAGCGAATCAAT GGACTCTGG$3^{\prime}$ and $5^{\prime}$-ACA TCACGCAT CAATTCCAC AA-3 ${ }^{\prime}$ (241 bp); the sense and antisense primers for caspase- 8 were $5^{\prime}$ AAGT TCCTGAGCCTGGACTACAT- $3^{\prime}$ and $5^{\prime}$-ATTTGAGCCCTGCCTGGTGTCT- $3^{\prime}$ (227 bp); the sense and antisense primers for p53 were $5^{\prime}$-GTCTACCTCCCGCCATAA $-3^{\prime}$ and $5^{\prime}$-CATCTCCCAAACATCCCT- $3^{\prime}$ (316 bp); the sense and antisense primers for NDRG1 were $5^{\prime}$-CCCTCGCGTTAGGCAGGTGA- $3^{\prime}$ and $5^{\prime}$-AGGGGTACATGTACCCTGCG-3' (370 bp); the sense and antisense primers for TFR1 were $5^{\prime}$-TCAGGTCAAAGACAG CGCTCAAAACTC$3^{\prime}$ and $5^{\prime}$-AG TCTCCTTCCATATTCCCAAACAGCTTTT$3^{\prime}$ (358 bp), respectively. The RT-PCR was performed on Nexus Gradient Mastercycler (Eppendorf). The cycling conditions were $94^{\circ} \mathrm{C}$ for $5 \mathrm{~min}$, followed by 30 cycles of $94^{\circ} \mathrm{C}$ for $30 \mathrm{~s}, 53-56^{\circ} \mathrm{C}$ for $30 \mathrm{~s}, 72^{\circ} \mathrm{C}$ for $1 \mathrm{~min}$, and a final extension of $72^{\circ} \mathrm{C}$ for $10 \mathrm{~min}$. PCR products were separated on the $1.5 \%$ agarose gel viewed by ethidium bromide staining. These data were acquired with Toucan 360 gel imager (version 3.2.1 software).

2.9. DNA Relaxation of Supercoiled pUC18 DNA. This assay was performed following the procedure reported $[15,16]$. The reaction mixture $(20 \mu \mathrm{L})$ contained relaxation buffer $(50 \mathrm{mM}$ Tris- $\mathrm{HCl}$ (pH 8.0), 0.5 mM EDTA, 1 mM DTT, $50 \mathrm{mM} \mathrm{NaCl}$, $10 \mathrm{mM} \mathrm{MgCl}_{2}$, and $30 \mu \mathrm{g} / \mathrm{mL} \mathrm{BSA}, 5 \%$ glycerol), $0.3 \mu \mathrm{g}$ of supercoiled pUC18 plasmid DNA, and increasing concentrations of the BNMPH. The reaction was initiated by adding 1 unit of human topoisomerase II $\alpha$ (Sigma) and incubated at $37^{\circ} \mathrm{C}$ for $45 \mathrm{~min}$. The reaction was terminated by adding $5 \mu \mathrm{L}$ of stopping buffer (10\% SDS, $25 \mathrm{mM}$ EDTA, $0.025 \%$ bromophenol blue, and $40 \%$ glycerol). The reaction products were analyzed by electrophoresis on $1 \%$ agarose gel using a TBE buffer $(89 \mathrm{mM}$ Tris- $\mathrm{HCl}, 89 \mathrm{mM}$ boric acid, and $62 \mathrm{mM}$ EDTA) at $30 \mathrm{~V}$ for $3 \mathrm{~h}$, stained by ethidium bromide $(0.5 \mu \mathrm{g} / \mathrm{mL})$, and photographed by a Toucan 360 gel imager (version 3.2.1 software).

2.10. Molecular Docking Studies. The structure of human type II DNA topoisomerase with DNA and etoposide (3QX3) was obtained from RCSB Protein Data Bank [17]. The BNMPH was generated from Chemdraw (Chemdraw Ultra 8.0) and the energy minimization was conducted by Chem3D (Ultra 8.0) [18]. The resulting models were displayed in PyMOl (The PyMOL Molecular Graphics System, Version 1.4.1, Schrödinger, LLC).

Molecular docking studies were performed by AutoDock Vina and AutoDock Tools based on the recommended procedure [19]. Grid boxes were set to the center of etoposide model, and the grid box size for BNMPH was set to 22, 24, and 28 for $X, Y$, and $Z$ axes, respectively. The BNMPH was set as a flexible ligand by using the default parameters of the AutoDock Tools. The optimal conformation of the ligand was generated by Autodock Vina. 


\section{Results}

3.1. The Cytotoxicity of the BNMPH. The previous study showed that the BNMPH can chelate many transition metals such as iron, copper, and zinc ion to form metal complexes; however, the evaluation of it and its metal complexes in anticancer activity was not fully conducted. To get insight of more information, BNMPH was evaluated against different tumor cell lines (HepG2, HCT-116, PC-12, and K562) by MTT method. The dose-response curves of BNMPH determined against the investigated cells are depicted in Figure 2. As shown in Figure 2, BNMPH could inhibit all the cell lines and had moderate growth inhibition in the K562 $(48.2 \pm 4.0 \mu \mathrm{M})$ and HCT-116 $(57.5 \pm 5.3 \mu \mathrm{M})$, stronger inhibition in HepG2 hepatocellular carcinoma cell line $(26.1 \pm 3.5 \mu \mathrm{M}$, accordingly the $\mathrm{IC}_{50}$ of cisplatin obtained by our lab was $18.9 \pm 2.4 \mu \mathrm{M}$ [20]), and significant inhibition for PC-12 cell line (19.4 \pm $2.2 \mu \mathrm{M})$.

3.2. BNMPH Induced ROS Generation. Many chemotherapeutic agents exhibit their antitumor activity via formation of reactive oxygen species (ROS). To assess whether BNMPH involved in ROS formation, the ROS assay was performed. As shown in Figure 3(a), BNMPH promoted ROS formation compared to Fenton reaction with significant increasing ( $\sim 6$ times) base on the fluorescent intensity (Figure 3(a)). It was interesting that BNMPH could also induce oxygen free radical formation in a time dependent manner, which implied that the BNMPH could chelate ferrous ion, and the formed complex was redox activity. In view of highly reactive feature of ROS and ROS causing oxidative damage of DNA, the cleavage of pUC18 by BNMPH-Fe ${ }^{2+}$ complex was assessed by agarose gel electrophoresis. As shown in Figure 3(b), the supercoiled pUC18 was decreased in the presence of $\mathrm{BNMPH}$, and accordingly the cleaved DNA was increased. So we speculated the cytotoxicity of BNMPH was correlated with ROS generation.

3.3. Cellular DNA Fragmentation In Vitro. ROS assay indicated that the BNMPH (or its iron complex) is redox active, and accordingly in vivo the ROS could cause genetic DNA breakage of host cell. To evaluate the potential effect of BNMPH on DNA integrity, the comet assay was conducted. As shown in Figure 3(c), BNMPH caused the cellular DNA breakage; the cometic tail of DNA is presented in the BNMPH treated K562 cells.

3.4. DNA Cross-Linking of BNMPH. To assess DNA crosslinking capacity of BNMPH, pUC18 DNA was used to react with varied $\mathrm{BNMPH}$ concentration, and the reaction products were subjected to alkaline agarose gel electrophoresis after BamH1 digestion (Figure 4(b)) [21]. As shown in Figure 4(b), BNMPH was able to induce DNA interstrand cross-linking, suggesting that BNMPH induced DNA crosslinking may also contribute to its cytotoxicity.

3.5. Thermal Denaturation. To further confirm the action mode of BNMPH with DNA, the effect of it on melting point of Ct-DNA was conducted. As shown in Figure 4(a), with increasing the temperature the absorbance at $260 \mathrm{~nm}$ of CtDNA solution was increased with double-helix dissociation to single strands since heat damages those hydrogen bonds. The melting temperature (Tm) of Ct-DNA was $72^{\circ} \mathrm{C}$ in the absence of BNMPH; however, the shift of the curve of CtDNA in the presence of BNMPH did not occur; conversely, it was fully flatted, indicating that the dissociation of doublehelical Ct-DNA was blocked. That was also indicative of covalent bond formed between stranded Ct-DNA.

3.6. BNMPH Gene Regulation. ROS play a crucial role in cell growth and apoptosis. BNMPH induced production of ROS in vitro encouraged us to investigate its gene regulation. So, the RT-PCR was conducted to determine the changes of apoptotic genes, such as p53, caspase-3, and caspase- 8 after the HepG2 cells were treated with BNMPH. As shown in Figure 5, the response of caspase- 3 and caspase- 8 was not parallel (Figure 5) and that of caspase- 3 and p53 was increased significantly, but caspase- 8 was not upregulated. In general, $\mathrm{N}$-myc downstream-regulated gene 1 (NDRG1), a metastasis suppressor, is upregulated by cellular iron depletion [22]. In view of the potent iron chelating ability of $\mathrm{BNMPH}$, the effect of it on regulation of metastatic and iron related gene, NDRG1 and TFR1 were also assessed by RT-PCR. Beyond our expectation, those genes were not affected by exposure of the BNMPH at the investigated concentrations. It might be indicative that the BNMPH was not involved in iron deprivation from ribonucleotide reductase as those inhibitors usually cause a G1/S or G2 arrest.

3.7. BNMPH Induced Cell Cycle Arrest at S Phase. It had been reported that DNA alkylating agents induced cell cycle delay and arrested the cell cycle progression predominantly at the G2/M boundary [23]. We therefore evaluated the effect of BNMPH on the cell cycle distribution using propidium iodide staining and flow cytometry. As shown in Figure 6, BNMPH caused an accumulation of cells in the $S$ phase of the cell cycle. The percentage of cells at the $S$ phase significantly increased from 19.04 to 35.99 and to $71.18 \%$ after treatment with 6 and $12 \mu \mathrm{M}$ BNMPH, respectively. The ability of BNMPH to induce $S$ cell cycle arrest in wildtype p53 containing HepG2 cells is also indicative of its p53-dependent mechanism [24], which was consistent with the upregulation of p53 in RT-PCR experiment. It was surprising that there was a difference in cell cycle arrest between BNMPH and the other nitrogen mustard containing derivatives $[21,23]$, which might reflect the sensitivity of the cells used to the test compound or dose dependent or different mechanism.

3.8. DNA Relaxation Inhibition. The effects of the BNMPH on topoisomerase II-mediated double strand DNA relaxation was carried out to test whether the BNMPH was topoisomerase II poisons. As shown in Figure 7(c), BNMPH was effective in preventing the conversion of supercoiled pUC18 to nicked closed circular DNA in a concentration dependent manner, indicating that it may inhibit topoisomerase II catalytic (relaxation) activity (Figure 7(c)). It almost eliminated 


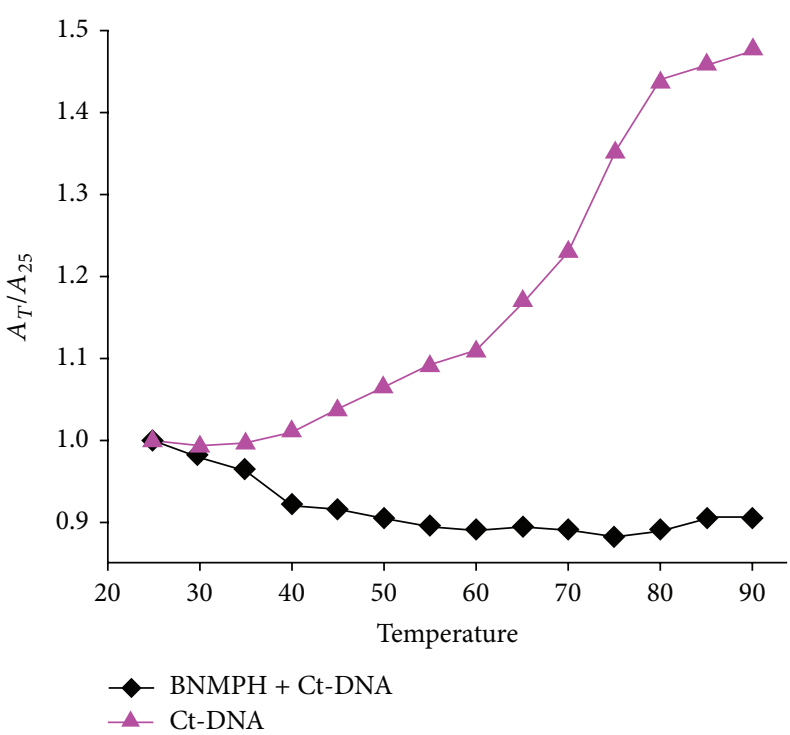

(a)

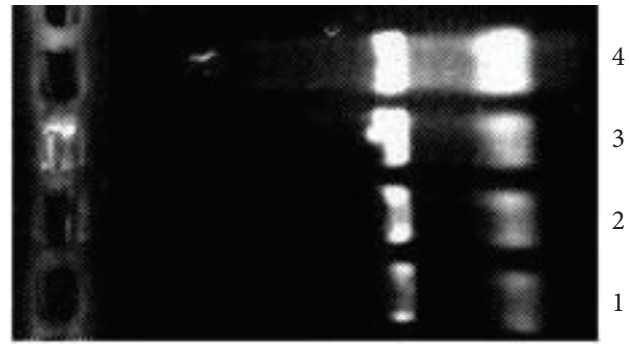

(1) No BNMPH

(2) $12.5 \mu \mathrm{M}$ BNMPH

(3) $25 \mu \mathrm{M}$ BNMPH

(4) $50 \mu \mathrm{M}$ BNMPH

(b)

FIgURE 4: DNA alkylation of BNMPH. (a) BNMPH effect on DNA thermal denaturation. The flatted curve (black) indicated that the dissociation of double stranded DNA was blocked during temperature rising due to cross-linking. (b) BNMPH induced DNA cross-linking. The cross-linked DNA was separated by electrophoresis and visualized by EB staining, and the concentrations used are as indicated.

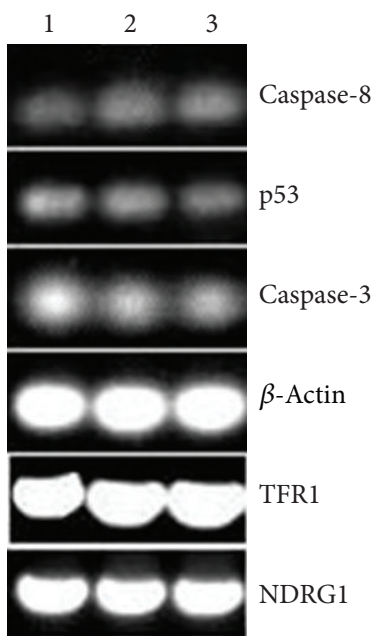

FIGURE 5: The effect of BNMPH on gene regulation. 1: $12 \mu \mathrm{M}$ $\mathrm{BNMPH}$; 2: $6 \mu \mathrm{M}$ BNMPH; 3: control, the genes in the figure as indicated.

the topoisomerase activity at $50 \mu \mathrm{M}$. On the other hand, it has been well documented that nitrogen mustard reacts preferably with sulfhydryl compounds, so the BNMPH reactivity with both DTT and BSA was investigated by spectral method, as shown in Figures 8(a) and 8(b). BNMPH indeed reacted with DTT, but the rate was not fast as the literature reported. We also observed that the rate of BNMPH which reacted with BSA was quite slow. In view of excess DTT $(0.5 \mathrm{mM})$ used in the topoisomerase inhibition assay, some of BNMPH could react with DTT; however, it was a little surprising that
BNMPH still showed the capacity in topoisomerase inhibition, so we speculated BNMPH exerted the inhibition might not be due to its reactivity with cysteine of topoisomerase, instead of interaction with catalytic (relaxation) domain.

3.9. Molecular Docking Studies. The topoisomerase inhibition of BNMPH in vitro demonstrated that BNMPH might be poisonous to topoisomerase Ii $\alpha$; however, many interaction modes could have occurred, that is, via alkylation of cysteine or binding at cleavage site or competition ATP binding site of topoisomerase complex. Due to slower reactivity of $\mathrm{BNMPH}$ with -SH group, especially with - $\mathrm{SH}$ group from protein, molecular docking was performed to assess possible interaction of BNMPH with topoisomerase. Based on the recommended procedure, the ligand free type II topoisomerase derived from 3QX3 (PDB ID: 3QX3) was chosen as receptor, and the $\mathrm{BNMPH}$ was used as ligand. The input pbdqt files were generated by Autodock tool, and the optimal conformations of ligand were calculated on Autodock Vina. The calculated data indicated that the docked BNMPH had a $-8.9 \mathrm{kcal} / \mathrm{mol}$ affinity energy with the DNA-topoisomerase complex. The orientation of the BNMPH and comparison of it with etoposide are shown in Figure 7(a) and Figure 7(b), respectively.

\section{Discussion}

Anticancer agents, such as paclitaxel, cisplatin, and doxorubicin induce apoptosis in most of the cancer cells through excess ROS formation $[25,26]$. Among those drugs, some have potential metal chelating ability, which usually are involved in ROS generation. As an attempt, we designed 


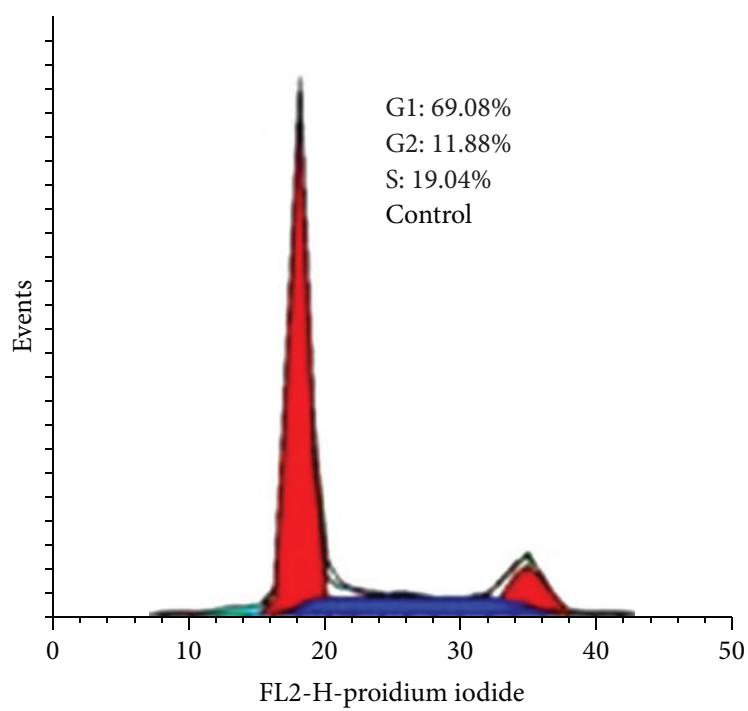

(a)

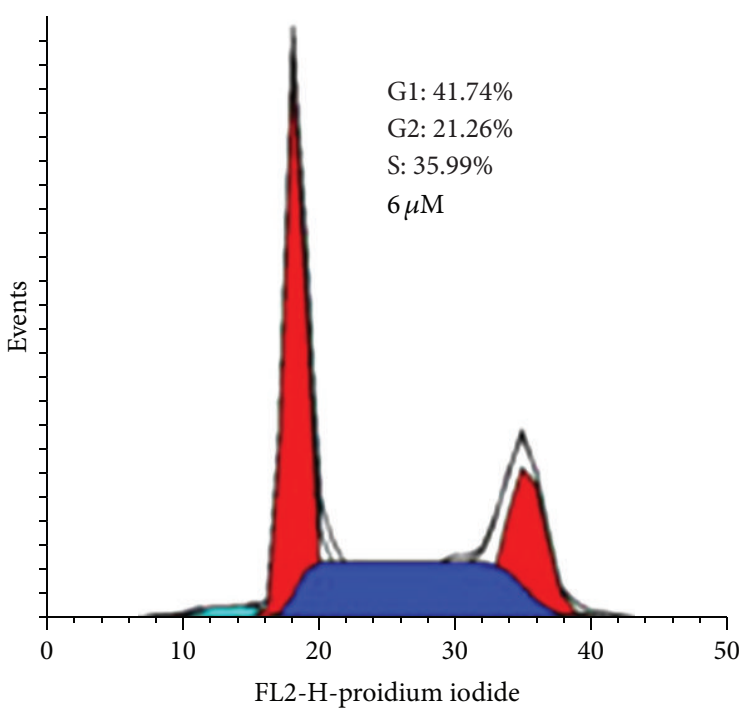

(b)

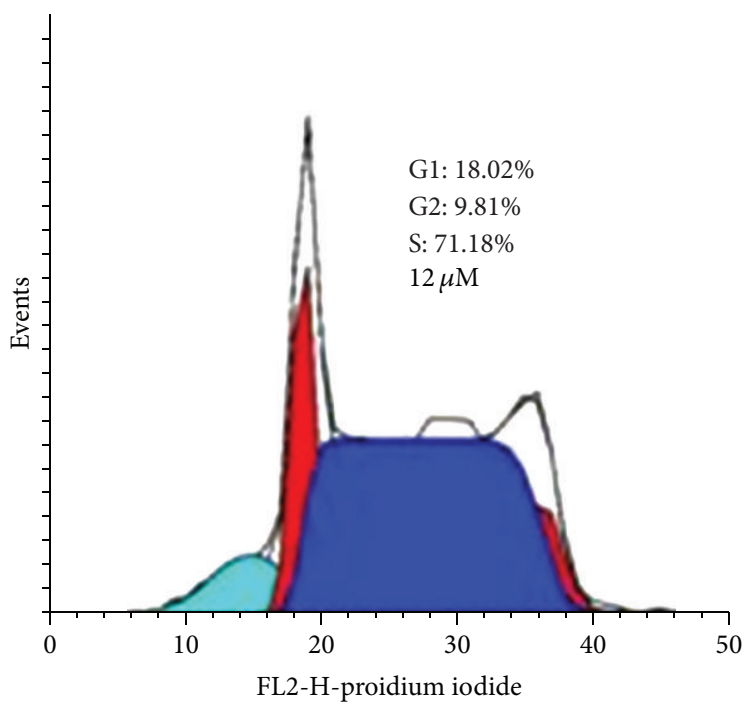

(c)

FIGURE 6: BNMPH induced cell cycle arrest. (a) Control; (b) $6 \mu \mathrm{M} \mathrm{BNMPH;} \mathrm{and} \mathrm{(c)} 12 \mu \mathrm{M}$ BNMPH, the cell distribution in the figure as indicated.

the BNMPH tethered both alkylating and chelation group in order to improve the drug's cytotoxicity. Previous study has shown that the BNMPH can chelate many transition metals, such as iron, copper, and zinc ion and exhibit definite biological activity. However, its anticancer activity, especially the underlying mechanism, was less concerned. Fenton reaction, a well-documented ROS generation system, can be used to determine whether BNMPH is involved in ROS production. Our data indicated that the BNMPH-iron complex is redox active; it can promote both production of hydroxyl and oxygen free radical in vitro. This encourages us to investigate the effect of BNMPH on cellular DNA integrity in vivo. It is well known that the ROS have ability to cause cellular DNA fragmentation, and comet assay is a sensitive method for quantifying and analyzing DNA damage and is widely used in evaluation of genotoxicity and effectiveness.
So, comet assay may provide useful information to determine whether the cytotoxicity exhibited BNMPH was involved in ROS generation. As expected, BNMPH indeed induced cellular DNA cleavage at higher concentration, indicating BNMPH's cytotoxicity may partly stem from ROS biological effect. It also prompts that iron chelating ability of BNMPH makes contribution to ROS generation; in other words, redox active BNMPH-Fe complex might be one of the poisons to host cell.

Nitrogen mustard derivatives as DNA alkylating agents can alkylate DNA via interstrand or intrastrand cross-linking (ICL), leading DNA lesions. It has been accepted that as a mechanism of inhibition or arrest of synthesis of DNA, other interactions, such as between DNA and proteins, including DNA polymerase at replication fork site may be also involved. BNMPH tethering an aromatic mustard could have similar 


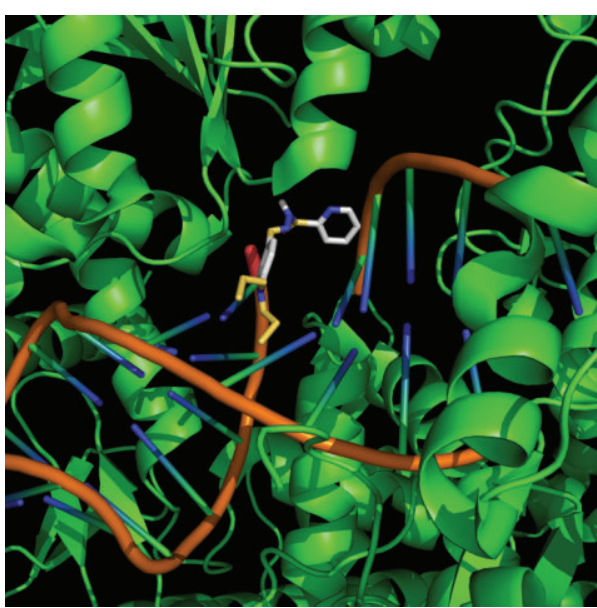

(a)

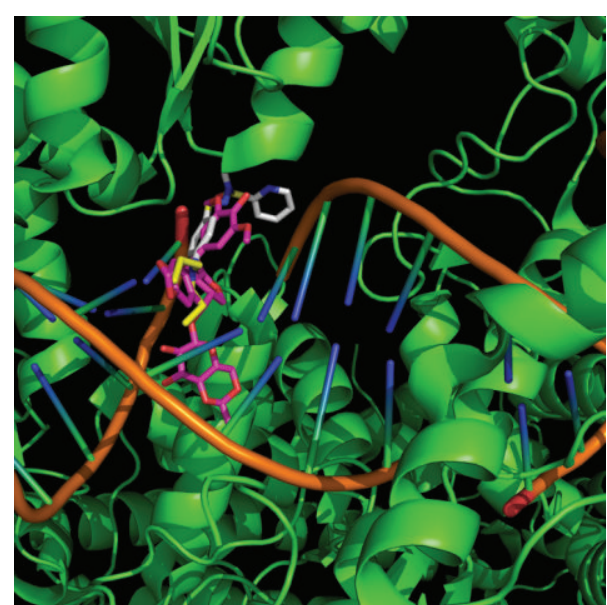

(b)

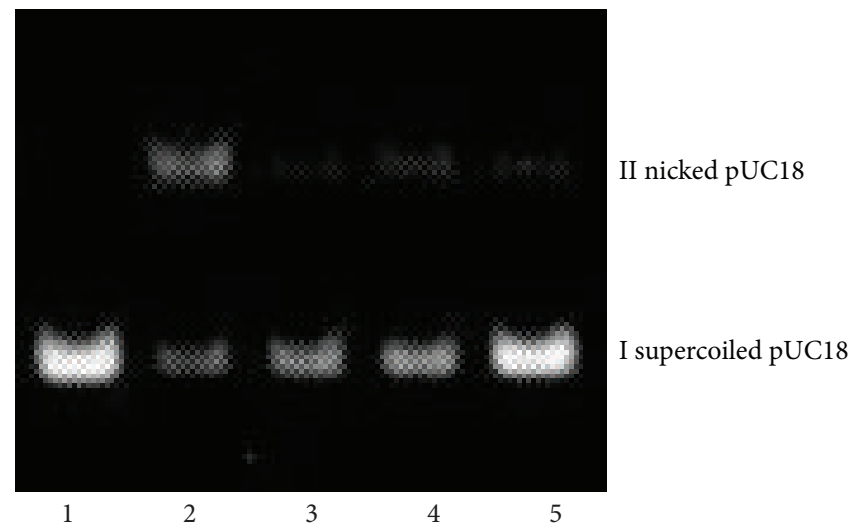

(1) pUC18

(2) pUC18 + Top II

(3) $\mathrm{pUC} 18+$ Top II $+12.5 \mu \mathrm{M}$ BNMPH

(4) $\mathrm{pUC} 18+$ Top II $+25 \mu \mathrm{M}$ BNMPH

(5) $\mathrm{pUC18}+$ Top II $+50 \mu \mathrm{M}$ BNMPH

(c)

FIgURE 7: Topoisomerase II inhibition of BNMPH. (a) The docked BNMPH in human topoisomerase II-DNA complex. (b) Comparison of BNMPH and etoposide in topoisomerase II complex. (c) Human topoisomerase II $\alpha$ inhibition of BNMPH. The concentration is used as indicated. At $50 \mu \mathrm{M}$ BNMPH almost blocked the topoisomerase catalyzed DNA relaxation.

function. As expected, the DNA alkylating ability of BNMPH was confirmed both by alkaline agarose gel shift assay and also the thermodenaturation of CT-DNA, in which the crosslinked DNA and blockage of DNA dissociation can be seen. In general, an ICL can lead to a stalled replication fork in S phase [27] and likely activate cell-cycle checkpoint and then arrest at late S to G2 [28] to repair the damaged DNA $[29,30]$. It is beyond our prediction that BNMPH induced HepG2 cell at $S$ phase arrest in a concentration dependent manner, which is a distinct difference from what the other alkylating agents did, but this situation was recently observed when HepG2 cells exposed to nitrogen mustard [31]. This may also indicate that there are other interactions, such as between DNA and proteins, including DNA polymerase, at replication fork site that may be also involved. Masta et al. demonstrated that nitrogen mustard can inhibit transcription and translation in a cell free system [32]. We also observed Taq DNA polymerase inhibition by BNMPH in PCR reaction, showing that the PCR products were decreased with increasing of BNMPH (data not shown). Thus, we speculate that BNMPH might be able to target transcription enzymes via alkylating cysteine, and consequently their enzymatic activities are lost or inhibited. On the other hand, to some extent, the reduction in fidelity of replication of DNA might contribute to the cytotoxicity of alkylating agents [33]. So the $S$ phase arrest caused by BNMPH might be involved in the mentioned above inhibitions. To evaluate whether the topoisomerase affects the cell cycle, topoisomerase II $\alpha$ inhibition of BNMPH was investigated; the data clearly indicate that $\mathrm{BNMPH}$ indeed interfere with the topoisomerase function, which implies that dysfunction of topoisomerase may also contribute to the cell cycle delay, but the mode of topoisomerase inhibition of 


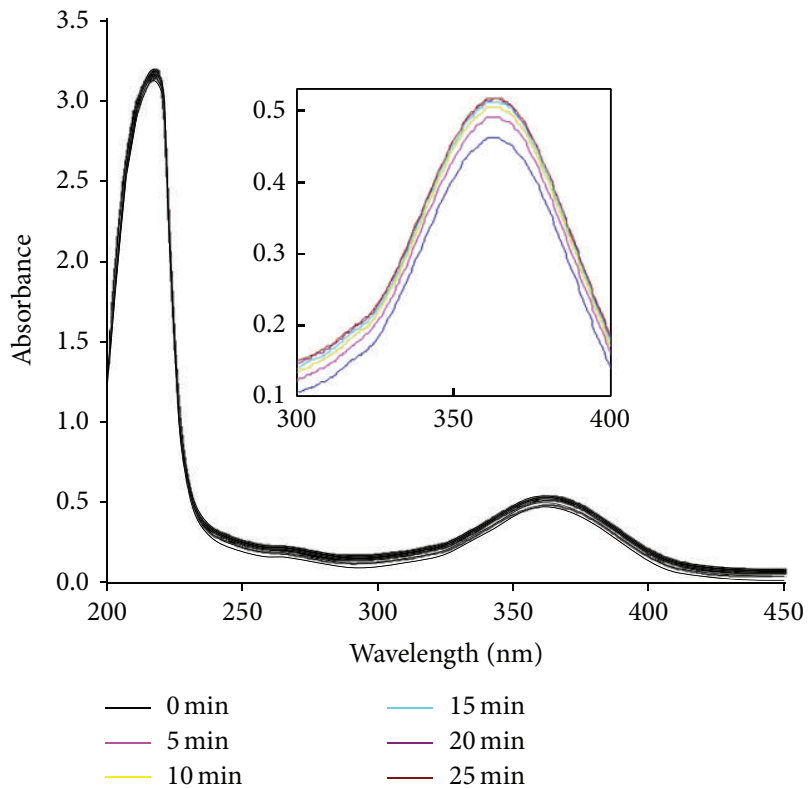

(a)

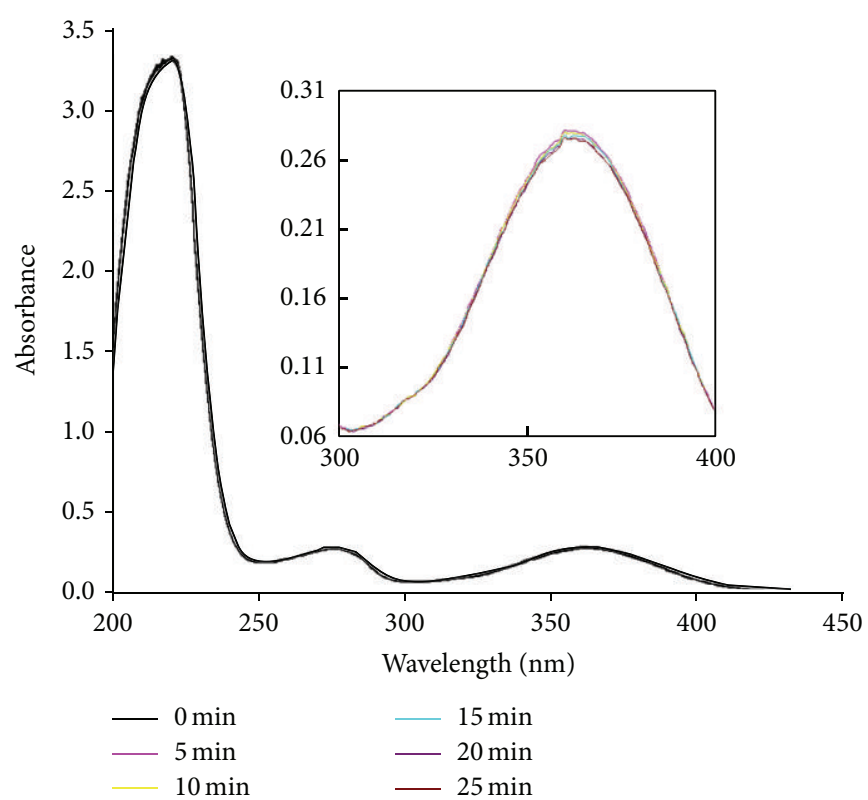

(b)

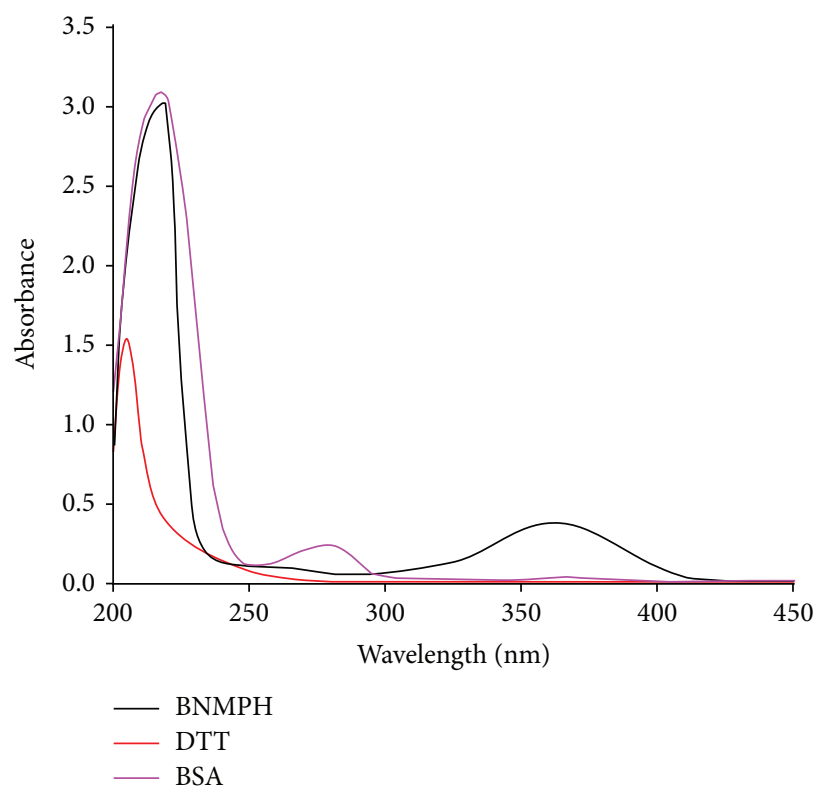

(c)

FIGURE 8: BNMPH reactivity with DTT and BSA. (a) The absorbance spectral changes of DTT after addition of $26 \mu \mathrm{M}$ BNMPH to $500 \mu \mathrm{M}$ DTT $\left(\mathrm{pH} 8.0,37^{\circ} \mathrm{C}\right)$. The spectrum was collected after the mixing, and subsequent spectrum at 5 min intervals was recorded. The insert showed a series of increases during the 25 min period, indicating that BNMPH can alkylate thiol group. (b) Spectrum of BNMPH (13 $\mu$ M) reacted with thiol of $\mathrm{BSA}(5 \mu \mathrm{M})$ in $\mathrm{pH} 8.0$ buffer at $37^{\circ} \mathrm{C}$; the insert showed no obvious changes during the 25 min period, indicating that $\mathrm{BNMPH}$ may react with thiol group of BSA at very low rate.

$\mathrm{BNMPH}$, via alkylating $\mathrm{SH}$, or other interactions is unclear. In view of reactivity of BNMPH with free -SH (DTT) and -SH from protein (BSA) is not strong (fast) based on our data. We speculate alkylating of - $\mathrm{SH}$ of topoisomerase might not be main contributor. To assess the possibility of "poising" of BNMPH to DNA-topoisomerase intermediate, molecular docking was conducted using available crystal structural data, revealing that the docked $\mathrm{BNMPH}$ has a moderate binding affinity with topoisomerase $(-8.9 \mathrm{kcal} / \mathrm{mol})$ compared to that redocked etoposide $(-14.6 \mathrm{kcal} / \mathrm{mol})$, indicating that the poising effect of BNMPH on DNA-topoisomerase intermediate cannot be excluded.

The involvement of reactive oxygen species (ROS) in induction of apoptosis of various cancer cells has been 
demonstrated in the literature [34-36]. The cytotoxicity of BNMPH could partly be due to ROS production. Under oxidative stress, the apoptosis related genes, such as caspase3 , caspase- 8 , and p53 will respond to the stress. As expected, the upregulation of p53 and caspase- 3 was observed after $24 \mathrm{~h}$ of exposure, indicating that the cytotoxicity of BNMPH was involved in apoptosis. However, the changes of TFR1 and NDRG1 genes were not obvious, which might indicate that the cytotoxicity of BNMPH was not correlated with the iron deprivation from ribonucleotide reductase. The cell cycle analysis seemed to be supportive of this. Generally iron chelators induce upregulation of TFR, NDRG1, and G2 arrest $[2,5,6]$. The $S$ phase delay induced by BNMPH may reflect the difference in coordination environment between BNMPH (bidentate) and iron chelators (tridentate). So, the $\mathrm{BNMPH}$ acquiring the iron for ROS generation might be from labile iron pool. Therefore, the cytotoxicity of BNMPH stems mainly from DNA alkylation, ROS generation, and topoisomerase inhibition.

\section{Conclusion}

In this work we evaluated the cytotoxicity and potent mechanism of BNMPH; the $\mathrm{IC}_{50}$ differences in the investigated cell lines reflect the sensitivity of BNMPH to cell lines. Like other nitrogen mustard derivatives, the $\mathrm{BNMPH}$ has the DNA alkylating ability to cross-link DNA. Iron chelating capacity of BNMPH also contributed to the ROS generation, which consequently induced apoptosis and DNA fragmentation of host cell. No changes of the Tfrl and NDRGlgene expression and cell cycle arrest at $S$ phase might indicate that the iron for ROS generation was not from ribonucleic reductase but from labile iron pool. Topoisomerase II $\alpha$ inhibition of BNMPH and molecular docking reveal the potent mechanism. Therefore, the conclusion can be drawn that the cytotoxicity of BNMPH may stem from ROS generation, DNA alkylating, and topoisomerase inhibition.

\section{Conflict of Interests}

The authors declare that there is no conflict of interests regarding the publication of this paper.

\section{Acknowledgments}

The authors would like to thank Mis Jing Meng, Qiaoli Liu, Yan Zhang, and Huan Wang for their help in experiments of thermal denaturation of Ct-DNA and ROS assay. This project was supported by Henan Science and Technology Agency (210073), Xinxiang Medical University (ZD2011006), and Xinxiang Scientific and Technology Division (CP1204).

\section{References}

[1] Y. Chen and L. Hu, "Design of anticancer prodrugs for reductive activation," Medicinal Research Reviews, vol. 29, no. 1, pp. 29-64, 2009.
[2] Z.-Q. Chen, D.-H. Zhang, F. Yue, M.-H. Zheng, Z. Kovacevic, and D. R. Richardson, "The iron chelators Dp44mT and DFO inhibit TGF- $\beta$-induced epithelial-mesenchymal transition via up-regulation of $\mathrm{N}$-Myc downstream-regulated gene 1 (NDRG1)," The Journal of Biological Chemistry, vol. 287, no. 21, pp. 17016-17028, 2012.

[3] A. Gupte and R. J. Mumper, "Elevated copper and oxidative stress in cancer cells as a target for cancer treatment," Cancer Treatment Reviews, vol. 35, no. 1, pp. 32-46, 2009.

[4] P. M. B. Pahl and L. D. Horwitz, "Cell permeable iron chelators as potential cancer chemotherapeutic agents," Cancer Investigation, vol. 23, no. 8, pp. 683-691, 2005.

[5] E. M. Becker, D. B. Lovejoy, J. M. Greer, R. Watts, and D. R. Richardson, "Identification of the di-pyridyl ketone isonicotinoyl hydrazone (PKIH) analogues as potent iron chelators and anti-tumour agents," The British Journal of Pharmacology, vol. 138, no. 5, pp. 819-830, 2003.

[6] T. B. Chaston, D. B. Lovejoy, R. N. Watts, and D. R. Richardson, "Examination of the antiproliferative activity of iron chelators: multiple cellular targets and the different mechanism of action of triapine compared with desferrioxamine and the potent pyridoxal isonicotinoyl hydrazone analogue 311," Clinical Cancer Research, vol. 9, no. 1 I, pp. 402-414, 2003.

[7] G. J. Finlay, W. R. Wilson, and B. C. Baguley, "Chemoprotection by 9-aminoacridine derivatives against the cytotoxicity of topoisomerase II-directed drugs," European Journal of Cancer and Clinical Oncology, vol. 25, no. 12, pp. 1695-1701, 1989.

[8] B. Marvania, P. C. Lee, R. Chaniyara et al., "Design, synthesis and antitumor evaluation of phenyl N-mustard-quinazoline conjugates," Bioorganic and Medicinal Chemistry, vol. 19, no. 6, pp. 1987-1998, 2011.

[9] C. Z. Li, L. F. Wang, X. Q. Meng, and H. Zhao, "Synthesis, characterization and antitumor activity of benzaldehyde nitrogen mustard picolinoyl hydrazone complexes," Transition Metal Chemistry, vol. 24, no. 2, pp. 206-209, 1999.

[10] C. Z. Li, J. G. Wu, L. F. Wang, M. Ren, N. R. Jia, and J. Guo, "Synthesis, characterization and antitumor activity of copper(II) complex with nicotinamido-4-bis (2-chloroethyl) aminobenzaldimine," Journal of Inorganic Biochemistry, vol. 73, no. 4, pp. 195-202, 1999.

[11] W. Jakubowski and G. Bartosz, "2,7-dichlorofluorescin oxidation and reactive oxygen species: what does it measure?" Cell Biology International, vol. 24, no. 10, pp. 757-760, 2000.

[12] N. Shahabadi, S. Kashanian, M. Mahdavi, and N. Sourinejad, "DNA interaction and DNA cleavage studies of a new platinum(II) complex containing aliphatic and aromatic dinitrogen ligands," Bioinorganic Chemistry and Applications, vol. 2011, Article ID 525794, 10 pages, 2011.

[13] N. P. Singh, M. T. McCoy, R. R. Tice, and E. L. Schneider, "A simple technique for quantitation of low levels of DNA damage in individual cells," Experimental Cell Research, vol. 175, no. 1, pp. 184-191, 1988.

[14] N. Lingthoingambi, N. R. Singh, and M. Damayanti, "DNA interaction and biological activities of copper(II) complexes of alkylamidio-O-methylurea," Journal of Chemical and Pharmaceutical Research, vol. 3, no. 6, pp. 187-194, 2011.

[15] N. Osheroff, E. R. Shelton, and D. L. Brutlag, "DNA topoisomerase II from Drosophila melanogaster. Relaxation of supercoiled DNA," The Journal of Biological Chemistry, vol. 258, no. 15, pp. 9536-9543, 1983. 
[16] D. A. Burden, S. J. Froelich-Ammon, and N. Osheroff, “Topoisomerase II-mediated cleavage of plasmid DNA," Methods in Molecular Biology, vol. 95, pp. 283-289, 2001.

[17] C. C. Wu, T. K. Li, L. Farh et al., "Structural basis of type II topoisomerase inhibition by the anticancer drug etoposide," Science, vol. 333, no. 6041, pp. 459-462, 2011.

[18] K. Ok, Y. W. Jung, J. G. Jee, and Y. Byun, "Facile docking and scoring studies of carborane ligands with estrogen receptor," Bulletin of the Korean Chemical Society, vol. 34, no. 4, pp. 10511054, 2013.

[19] O. Trott and A. J. Olson, "Software news and update AutoDock Vina: improving the speed and accuracy of docking with a new scoring function, efficient optimization, and multithreading," Journal of Computational Chemistry, vol. 31, no. 2, pp. 455-461, 2010.

[20] Y. Fu, S. F. Zhou, D. Y. Li, Y. F. Zhang, S. S. Li, and C. Z. Li, "Ciprofloxacin inhibits proliferation and synergistic effect against hepatocellular carcinoma cancer lines with cisplatin," African Journal of Pharmacy and Pharmacology, vol. 7, no. 26, pp. 1793-1801, 2013.

[21] N. Kapuriya, R. Kakadiya, H. Dong et al., "Design, synthesis, and biological evaluation of novel water-soluble $\mathrm{N}$-mustards as potential anticancer agents," Bioorganic and Medicinal Chemistry, vol. 19, no. 1, pp. 471-485, 2011.

[22] J. Sun, D. Zhang, Y. Zheng et al., "Targeting the metastasis suppressor, NDRG1, using novel iro chelators: regulation of stress fiber-mediated tumor cell migration via modulation of the ROCK1/pMLC2 signaling pathway," Molecular Pharmacology, vol. 83, no. 2, pp. 454-469, 2013.

[23] M. J. O'Connell, N. C. Walworth, and A. M. Carr, "The G2-phase DNA-damage checkpoint," Trends in Cell Biology, vol. 10, no. 7, pp. 296-303, 2000.

[24] T. K. Lee, T. C. Lau, and I. O. Ng, "Doxorubicin-induced apoptosis and chemosensitivity in hepatoma cell lines," Cancer Chemotherapy and Pharmacology, vol. 49, no. 1, pp. 78-86, 2002.

[25] A. K. Maiti, "Reactive oxygen species reduction is a key underlying mechanism of drug resistance in cancer chemotherapy," Chemotherapy, vol. 1, no. 2, pp. 1-5, 2012.

[26] Q. Wang, X. L. Zheng, L. Yang et al., "Reactive oxygen speciesmediated apoptosis contributes to chemosensitization effect of saikosaponins on cisplatin-induced cytotoxicity in cancer cells," Journal of Experimental and Clinical Cancer Research, vol. 29, article 159, 2010.

[27] M. L. G. Dronkert and R. Kanaar, "Repair of DNA interstrand cross-links," Mutation Research-DNA Repair, vol. 486, no. 4, pp. 217-247, 2001.

[28] M. Ben-Yehoyada, L. C. Wang, I. D. Kozekov, C. J. Rizzo, M. E. Gottesman, and J. Gautier, "Checkpoint signaling from a single DNA interstrand crosslink," Molecular Cell, vol. 35, no. 5, pp. 704-715, 2009.

[29] B. B. Zhou and S. J. Elledge, "The DNA damage response: putting checkpoints in perspective," Nature, vol. 408, no. 6811, pp. 433-439, 2000.

[30] T. Osawa, D. Davies, and J. A. Hartley, "Mechanism of cell death resulting from DNA interstrand cross-linking in mammalian cells," Cell Death and Disease, vol. 2, no. 8, article e187, 2011.

[31] S. D. Feng and H. Y. Ling, "An investigation of the probable mechanism of nitrogen mustard to suppress liver cancer HepG2 cells growth," Journal of Medical Science in Central South China, vol. 39, no. 5, pp. 23-26, 2011.
[32] A. Masta, P. J. Gray, and D. R. Phillips, "Nitrogen mustard inhibits transcription and translation in a cell free system," Nucleic Acids Research, vol. 23, no. 17, pp. 3508-3515, 1995.

[33] L. P. Bignold, "Alkylating agents and DNA polymerases," Anticancer Research, vol. 26, no. 2, pp. 1327-1336, 2006.

[34] B. I. Fedeles, A. Y. Zhu, K. S. Young et al., "Chemical genetics analysis of an aniline mustard anticancer agent reveals complex I of the electron transport chain as a target," The Journal of Biological Chemistry, vol. 286, no. 39, pp. 33910-33920, 2011.

[35] D. G. Deavall, E. A. Martin, J. M. Horner, and R. Roberts, “Druginduced oxidative stress and toxicity," Journal of Toxicology, vol. 2012, Article ID 645460, 13 pages, 2012.

[36] M. L. Circu and T. Y. Aw, "Reactive oxygen species, cellular redox systems, and apoptosis," Free Radical Biology and Medicine, vol. 48, no. 6, pp. 749-762, 2010. 

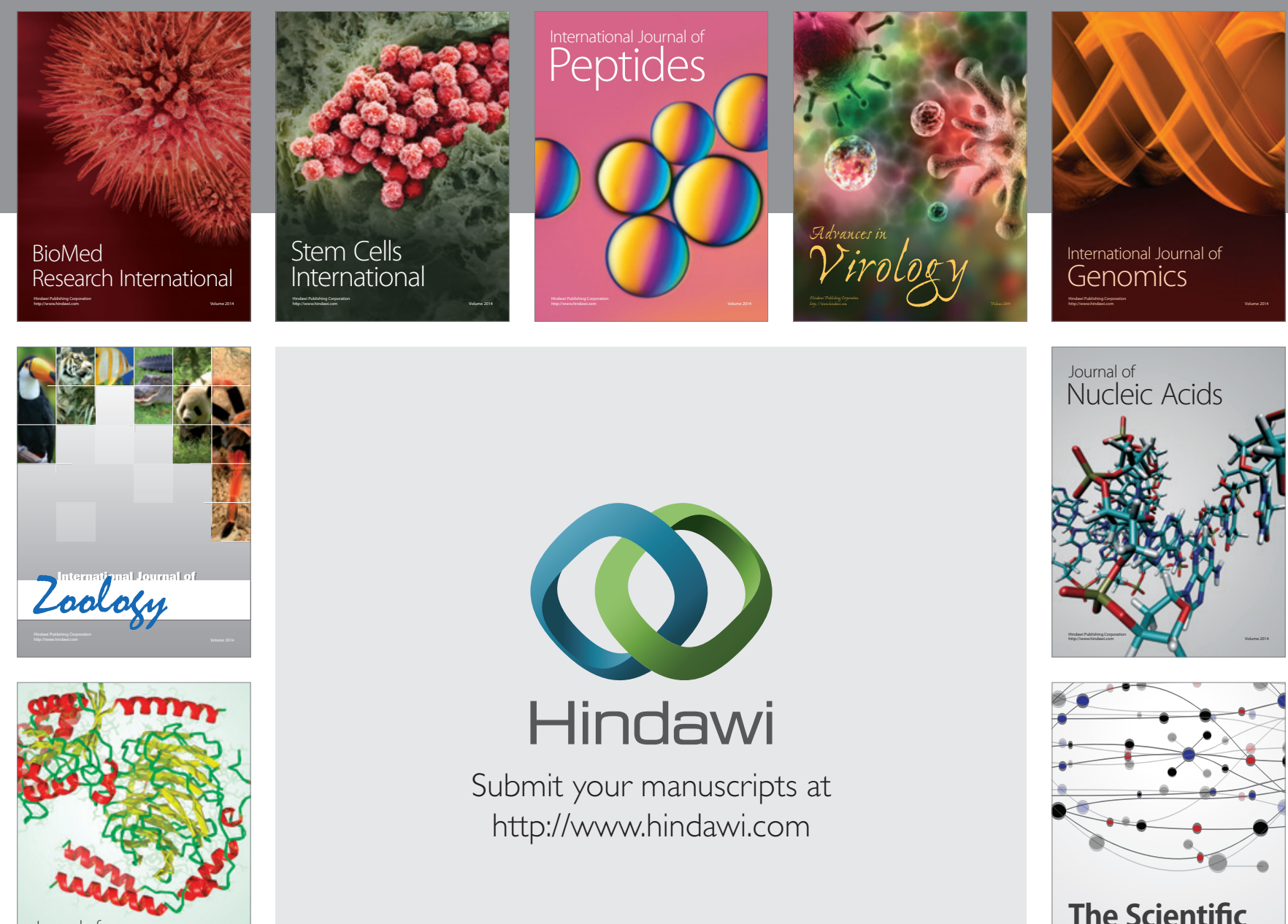

Submit your manuscripts at

http://www.hindawi.com

Journal of
Signal Transduction
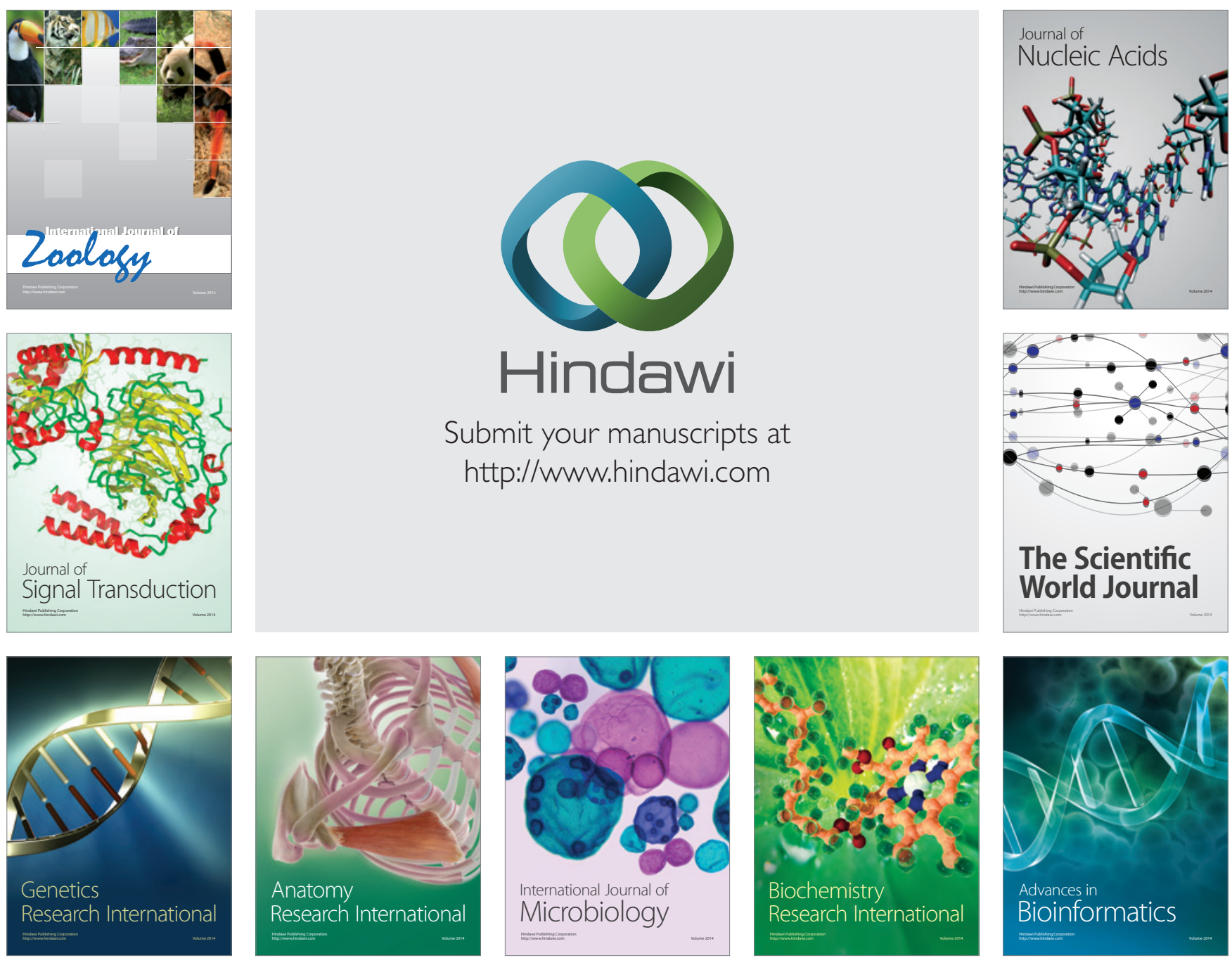

The Scientific World Journal
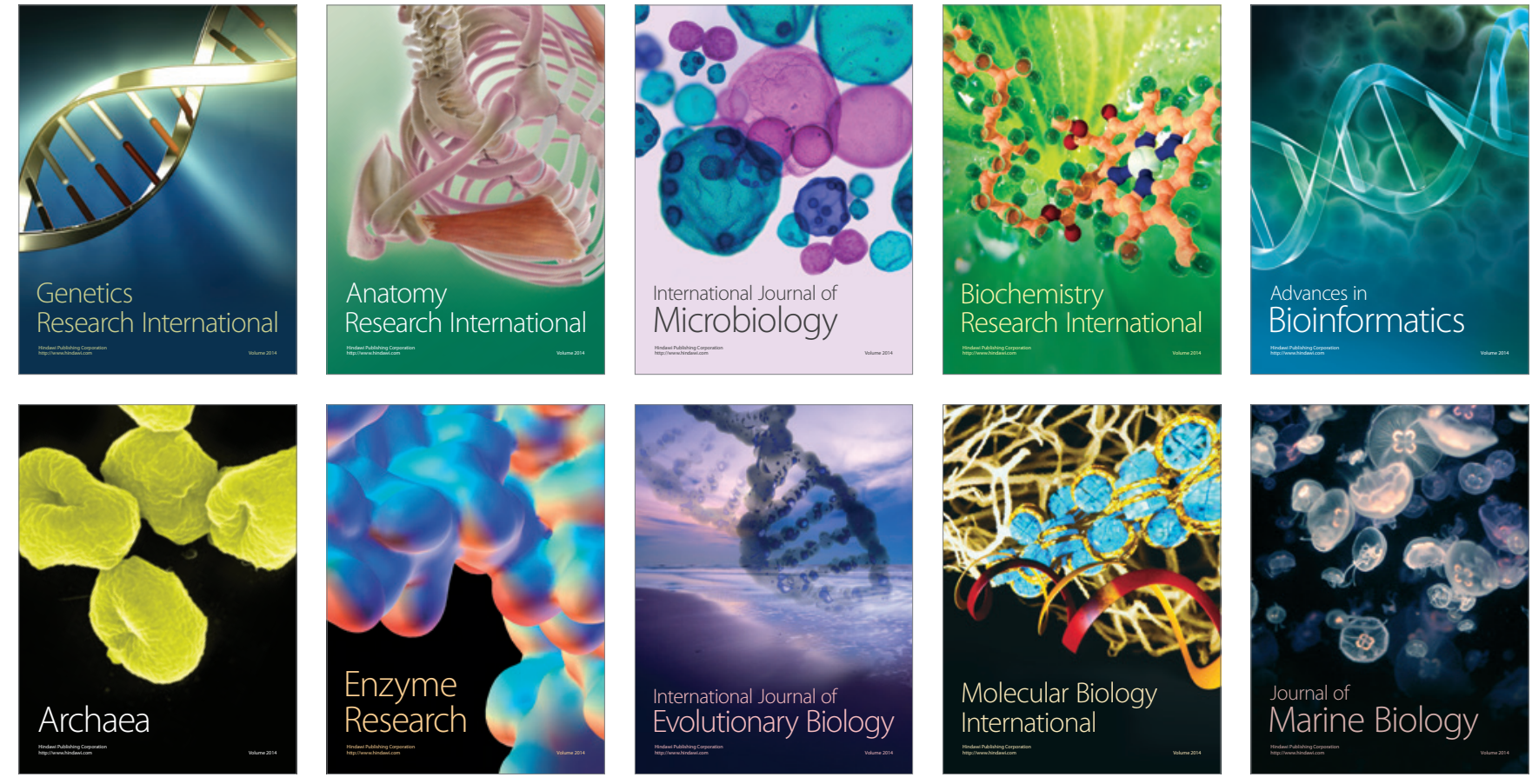